\title{
KAJIAN KOMPARATIF PEMODELAN AIR TANAH MENGGUNAKAN SISTEM INFORMASI GEOGRAFIS DI DESA KAYUAMBON, KABUPATEN BANDUNG BARAT
}

\author{
Millary Agung Widiawaty ${ }^{1}$, Moh. Dede ${ }^{2}$, Arif Ismail ${ }^{3}$ \\ 1,2Departemen Pendidikan Geografi, Universitas Pendidikan Indonesia \\ 3 Survei Pemetaan dan Informasi Geografis, Universitas Pendidikan Indonesia \\ 1'
}

\begin{abstract}
Nowadays, fresh water availability is a problem and require serious attention from all parties. Urbanization in Kayuambon Village causes highly growth population and require fresh water to support the needs, it resources come from groundwater. This research aims to determine the groundwater direction and accumulation based on groundwater modeling using IDW, Kriging, Spline, and Minimum Curvature interpolation techniques. Result shows that Kriging interpolation technique has the highest validity then others with $M E=0.316833, R M S E=$ 10.68147 , and $R^{2}=0.88934$. Groundwater modeling results also found that Kayuambon Village has two cone of depression are located in the central and northern of the village which known as concentration of groundwater flow. This study is expected to be a consideration for people and stakeholders to realize sustainable groundwater utilization.
\end{abstract}

Keywords: GIS, Groundwater Modelling, Interpolation Technique

\begin{abstract}
ABSTRAK
Ketersediaan air bersih saat ini menjadi masalah yang memerlukan perhatian serius dari berbagai pihak. Urbanisasi di Desa Kayuambon menyebabkan wilayah ini mengalami lonjakan populasi yang pesat dan memerlukan ketersediaan air guna menunjang kebutuhan penduduk salah satunya berasal dari air tanah. Penelitian ini bertujuan untuk mengetahui arah dan akumulasi air tanah melalui groundwater modelling berbasis SIG menggunakan teknik interpolasi IDW, Kriging, Spline, dan Minimum Curvature. Penelitian ini menunjukan bahwa teknik interpolasi Kriging memiliki validitas tertinggi dengan $\mathrm{ME}=0.316833, \mathrm{RMSE}=10.68147, \mathrm{dan} \mathrm{R}^{2}=0.88934$. Dari hasil pemodelan air tanah ditemukan bahwa Desa Kayuambon memiliki dua cone of depression yang berada di bagian tengah dan utara desa sebagai zona konsentrasi aliran air tanah. Hasil penelitian ini diharapkan mampu menjadi pertimbangan bagi masyarakat dan pihak terkait dalam melakukan kegiatan pemanfaatan air tanah secara berkelanjutan.

Kata Kunci: GIS, Groundwater Modelling, Interpolation Technique
\end{abstract}

\section{PENDAHULUAN}

Laju pertumbuhan penduduk berimplikasi terhadap kebutuhan air bersih yang semakin meningkat baik secara kuantitas maupun kualitas untuk berbagai aktivitas manusia seperti rumah tangga, pertanian, dan industri (UNESCO, 2005). Ketersediaan sumber daya air di daratan, sebagian besar berada di bawah permukaan tanah yang dikenal sebagai air tanah (Winter dkk., 1998; Saldanela dkk., 2015). Potensi air tanah di suatu wilayah dipengaruhi oleh dimensi akuifer, karakteristik hidrolika, iklim, topografi, kondisi geologis dan geomorfologis, serta kondisi penutup lahan (Anugrahadi dkk., 2017). 
Distribusi air tanah dapat diketahui melalui pemetaan pemodelan air tanah atau groundwater modelling. Pemodelan air tanah berguna untuk memahami sistem air tanah, pengelolaan sumber air tanah, dan perencanaan pemenuhan air (Kresic, 2007). Pemodelan air tanah dilakukan menggunakan persamaan matematis yang mewakili real world sistem hidrogeologis (Kumar, 2015; Qiu dkk., 2015). Teknik pemodelan air tanah dikelompokkan menjadi tiga kategori yakni fisik, analog, dan matematis (Baalousha, 2011). Dalam penelitian ini, pemodelan air tanah dilakukan berdasarkan metode matematis melalui teknik interpolasi guna mengetahui keberadaan cekungan air tanah (cone of depression). Setiap teknik interpolasi akan menghasilkan informasi yang berbeda, namun mengarah kecenderungan sama (Pramono, 2008).

Tonkin dan Larson (2001) mengungkapkan bahwa teknik interpolasi Kriging dalam pemodelan air tanah memberikan informasi korelasi tinggi muka air tanah dengan konduktivitas hidrolik. Studi komparasi berbagai teknik interpolasi dalam memodelkan tinggi muka air tanah menunjukan bahwa teknik interpolasi Simple Kriging memiliki validitas tertinggi (Xiaou dkk., 2016). Hasil berbeda ditunjukan oleh penelitian Charoenpong dkk. (2012), dimana teknik interpolasi IDW memiliki akurasi lebih tinggi daripada teknik interpolasi Kriging dan Spline.

\begin{tabular}{lll}
\multicolumn{1}{c}{ Berbeda } & dengan & penelitian \\
sebelumnya & yang & cenderung \\
menggunakan & teknik & interpolasi
\end{tabular}
deterministik, penelitian ini berusaha mengkomparasikan empat jenis teknik interpolasi IDW, Kriging, Spline, dan Minimum Curvature dalam pemodelan air tanah yang akan divalidasi secara geostatistik. Selain itu, penelitian ini juga berusaha mengkaji distribusi aliran air tanah dan cone of depression menggunakan sistem informasi geografis di Desa Kayuambon. Melalui penelitian ini diharapkan mampu memberikan informasi bagi seluruh stakeholder dan masyarakat dalam melakukan eksploitasi air tanah secara berkelanjutan.

\section{METODE \\ Lokasi Penelitian}

Penelitian ini dilakukan di Desa Kayuambon, Kecamatan Lembang, Kabupaten Bandung Barat, Jawa Barat yang secara geografis berada pada koordinat 107\% 37' 7,02" E - 107o 38' 35,94" E dan 6o 49' 39,55 S - 6० 48' 35,14" S (lihat gambar 1). Berada pada elevasi 1199 mdpl, wilayah ini memiliki formasi batuan berupa tuff dan andesit dengan kondisi topografis yang datar hingga curam (Silitonga, 1973). Desa Kayuambon termasuk ke dalam Sub DAS Cikapundung Hulu dengan curah hujan rata-rata tahunan mencapai 1709,1 $\mathrm{mm} /$ tahun dan suhu udara rata-rata mencapai 23,11 $\circ \mathrm{C}$, sedangkan dari segi penggunaan lahan didominasi oleh lahan terbangun seperti pemukiman (BPS Kab. Bandung Barat, 2016).

\section{Akuisisi Data dan Metode Analisis}

Dalam penelitian ini, sampel air tanah diperoleh beberaoa sumur yang tersebar di Kayuambon dengan parameter berupa elevasi, kedalaman sumur, diameter sumur, serta tinggi muka air pada November 2017. Data koordinat, dan tinggi muka air sumur diperlukan untuk analisis interplolasi menggunakan ArcGIS dengan teknik interpolasi Kriging, Spline, Minimum Curvature, dan IDW (Gambar 1).

Hasil analisis interpolasi dapat memberikan validasi arah aliran (flownet) dan cone of depession air tanah (Kresic, 2007). Nilai interpolasi dari berbagai teknik tersebut akan dianalisis menggunakan parameter Mean Error, RMSE, dan $\mathrm{R}^{2}$. Dalam analisis geostatistik tingkat validitas ditunjukan oleh nilai 
Mean Error dan RMSE yang kecil, serta nilia $\mathrm{R}^{2}$ yang tinggi (Sarangi dkk., 2005; Xiao dkk., 2016).

\section{Teknik Interpolasi Muka Air Tanah}

Inverse Distance Weight (IDW)

Teknik interpolasi ini mengasumsikan setiap plot mempunyai pengaruh yang bersifat lokal dan nilai plot tersebut akan semakin berkurang terhadap jarak (Pasaribu dan Haryani, 2012). Jarak yang dimaksud disini adalah jarak (datar) dari titik data (sampel) terhadap blok yang akan diestimasi. Teknik interpolasi IDW dapat ditentukan dengan persamaan berikut.

$$
\begin{aligned}
& \mathrm{u}(\mathrm{x})=\frac{\sum_{\mathrm{i}=1}^{\mathrm{N}} \mathrm{w}_{\mathrm{i}}(\mathrm{x}) \mathrm{u}_{\mathrm{i}}}{\sum_{\mathrm{i}=1}^{\mathrm{N}} \mathrm{w}_{\mathrm{i}}(\mathrm{x})} \\
& \mathrm{w}_{\mathrm{i}}(\mathrm{x})=\frac{1}{\mathrm{~d}\left(\mathrm{x}, \mathrm{x}_{\mathrm{i}}\right)^{\mathrm{p}}}
\end{aligned}
$$

(Persamaan 1)

(Persamaan 2)
Dimana U merupakan nilai yang diestimasikan dengan $\mathrm{Wi}$ sebagai nilai pada titik I. $X_{i}$ merupakan titik yang diketahui nilainya, sedangan $d$ dan $p$ merupakan jarak antar titik; daya pengaruh.

\section{Spline}

Teknik interpolasi Spline merupakan metode yang cukup baik untuk mengestimasi nilai yang tidak terdapat pada sampel data. Pada teknik spline, model permukaan yang dihasilkan akan tepat melewati titik-titik sampel. Teknik ini merupakan teknik interpolasi yang cukup akurat walaupun data yang digunakan hanya sedikit (Kresic, 2007). Teknik interpolasi Spline dapat dilakukan dengan menggunakan persamaan berikut.

$$
S(x, y)=T(x, y)+\sum_{j=1}^{N} \lambda_{j} R\left(r_{j}\right) \quad \text { (Persamaan 3) }
$$

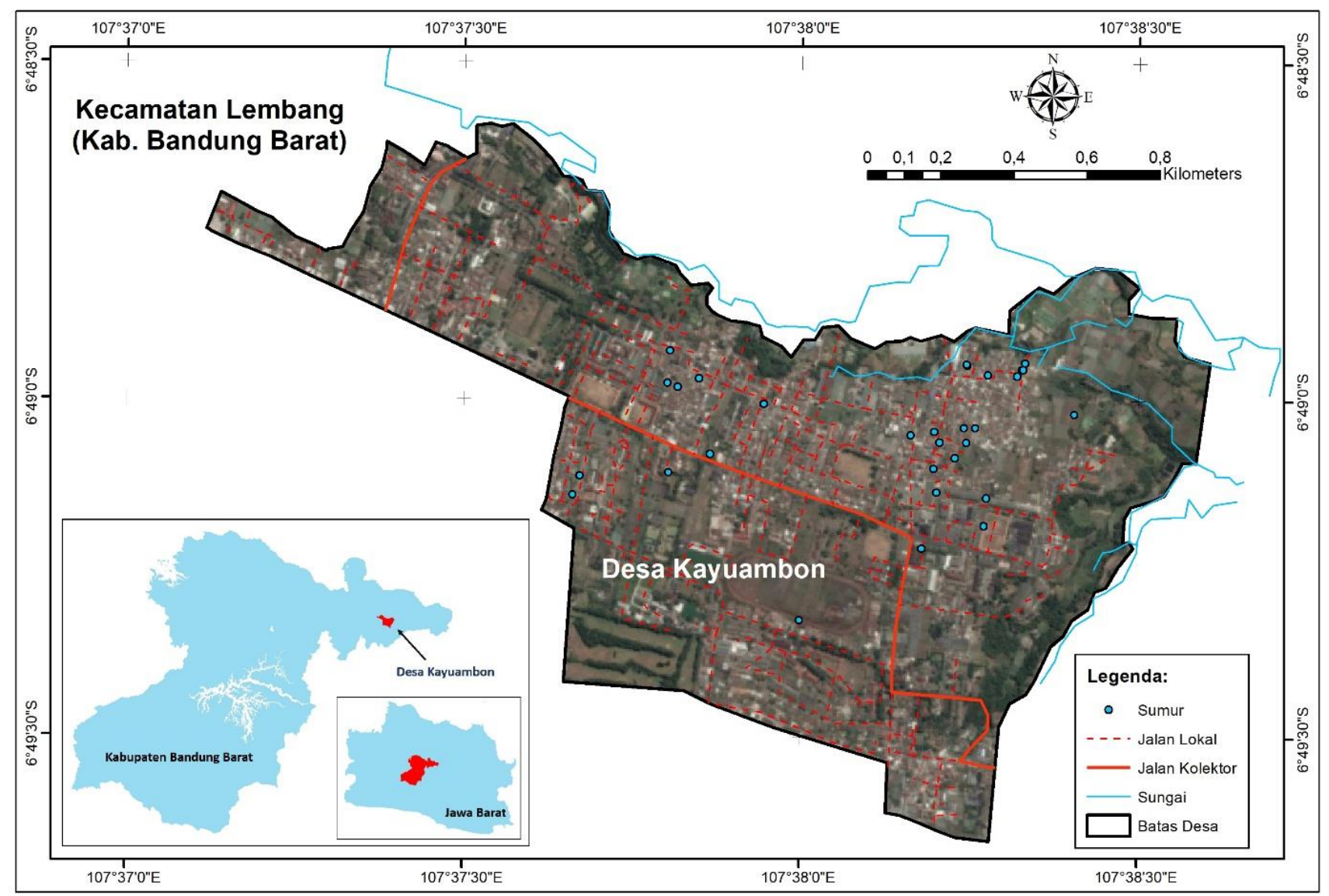

Sumber: Hasil Analisis, 2018

Gambar 1. Lokasi Penelitian 


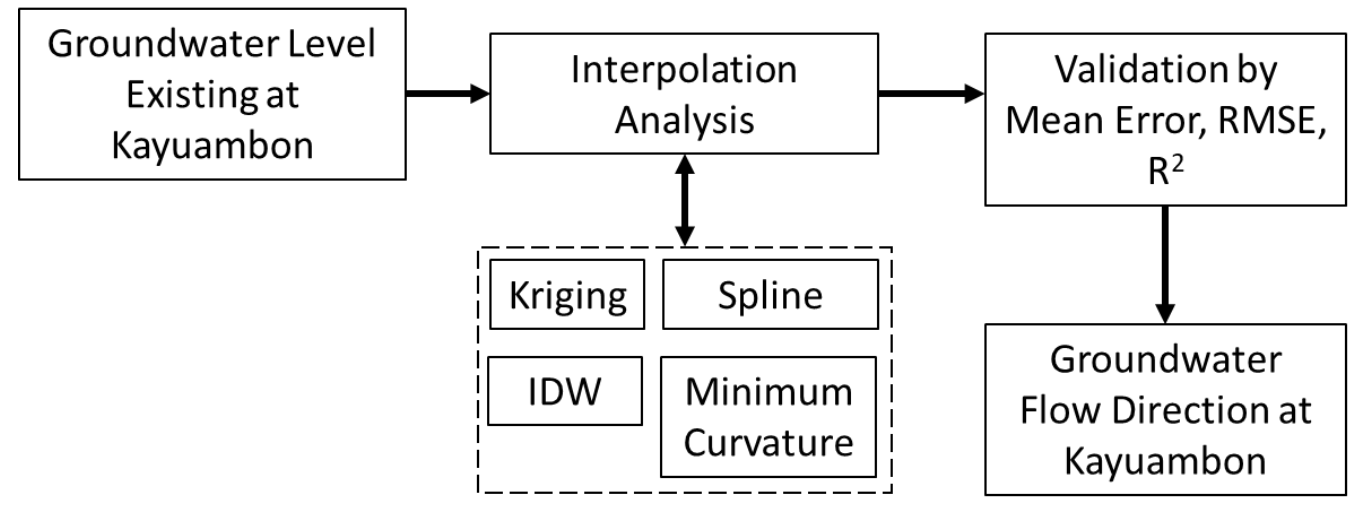

Gambar 2. Alur Penelitian

Dimana $S$ merupakan nilai untuk lokasi yang diestimasi dengan $\lambda_{j}$ sebagai koefisien persamaan linear dan $r_{j}$. adalah Jarak dari titik $(x, y)$ ke titik $j^{\text {th }}$. Sedangkan $\mathrm{T}(\mathrm{x}, \mathrm{y})$ dan $\mathrm{R}(\mathrm{r})$ didefinisikan secara berbeda berdasarkan cara seleksi baik itu regularized spline maupun tension spline.

\section{Kriging}

Teknik interpolasi Kriging dapat digolongkan dalam interpolasi stochastic yang menawarkan penilaian secara prediktif, karena mengasumsikan nilai kesalahan secara random. Teknik ini digunakan untuk mengestimasi nilai $\mathrm{z}$ pada titik yang tidak tersampel berdasarkan informasi dari karakteristik nilai $\mathrm{z}$ tersampel yang berada pada wilayah sekitarnya. Selain itu, teknik ini juga mempertimbangkan korelasi spasial antar data menggunakan semivariogram (Sun et. al, 2009, Hadi, 2013). Semivariogram Kriging dapat ditentukan dengan persamaan berikut.

$$
\begin{aligned}
& y(h)=\frac{1}{2 n} \sum_{i=1}^{n}\left\{Z\left(x_{i}\right)\right. \\
& -Z\left(x_{i}+h\right\}^{2}
\end{aligned}
$$

(Persamaan 4)

Keterangan:

$\mathrm{y}=$ nilai yang diestimasi

$\mathrm{Z}=$ nilai merupakan nilai pada titik $\mathrm{x}$ ke-i

$\mathrm{h}=$ merupakan jarak.

\section{Minimum Curvature}

Teknik ini dapat dianalogikan sebagai bidang elastis yang disebarkan ke seluruh titik data, sehingga hanya sedikit lekukan yang terjadi. Minimum Curvature memberikan hasil interpolasi yang lebih halus, sehingga tergolong interpolator non-eksak (Keckler, 1994; Dressler, 2009). Kelemahan teknik ini adalah kecenderungan mengekstrapolasikan nilai di daerah yang tidak ada datanya. Teknik interpolasi minimum curvature dapay diperoleh menggunakan persamaan berikut.

$$
\begin{array}{ll}
\text { North }=\frac{M D}{2} & \text { (Persamaan 5) } \\
{\left[\sin \left(\mathrm{I}_{1}\right) \times \cos \left(\mathrm{A}_{1}\right)+\sin \left(\mathrm{I}_{2}\right) \times \cos \left(\mathrm{A}_{2}\right)\right] \mathrm{RF}} & \\
\begin{array}{l}
\text { East }=\frac{\mathrm{MD}}{2} \\
{\left[\sin \left(\mathrm{I}_{1}\right) \times \cos \left(\mathrm{A}_{1}\right)+\sin \left(\mathrm{I}_{2}\right) \times \cos \left(\mathrm{A}_{2}\right)\right] \mathrm{RF}}
\end{array} & \text { (Persamaan 6) } \\
\mathrm{TVD}=\frac{\mathrm{MD}}{2}\left[\cos \left(\mathrm{I}_{1}\right)+\cos \left(\mathrm{I}_{2}\right)\right] \mathrm{RF} & \text { (Persamaan 7) } \\
\beta=\cos ^{-1}\left[\cos \left(\mathrm{I}_{2}-\mathrm{I}_{1}\right)-\left(\sin \left(\mathrm{I}_{1}\right) \times \sin \left(\mathrm{I}_{2}\right) \times(1-\right.\right. & \text { (Persamaan 8) } \\
\left.\left.\cos \left(\mathrm{A}_{2}-\mathrm{A}_{1}\right)\right)\right] & \text { (Persamaan 9) } \\
\mathrm{RF}=\frac{2}{\beta} \times \tan \left(\frac{\beta}{2}\right) &
\end{array}
$$

\section{Keterangan:}

$\mathrm{MD}=$ Measured Depth yang diperoleh dari hasl survei

TVD = True Vertical Depth

$\mathrm{RF}=$ rasio factor

$\beta=$ dog leg angle

$\mathrm{I}_{1}$ maupun $\mathrm{I}_{2}=$ sudut inklinasi atas dan bawah, 
HASIL DAN PEMBAHASAN

Pemodelan Air Tanah

Penelitian ini menggunakan sampel sebanyak 30 sumur yang tersebar di Desa Kayuambon untuk mesimulasikan ketinggian dan akumulasi air tanah. Validasi pemodelan air tanah dilakukan secara silang antar teknik interpolasi, dimana teknik interpolasi dengan nilai error terendah dan korelasi tertinggi merupakan yang terbaik, perbandingan tiap parameter untuk setiap metode interpolasi (tabel 1).

Hasil dari validasi pengamatan tinggi muka air eksisting dengan pemodelan, secara berurutan didapatkan bahwa nilai Mean Error (ME) IDW < Kriging < Minimum Curvature < Spline. Sedangkan Root Mean Square Error (RMSE) diperoleh Kriging $<I D W<$ Minimum
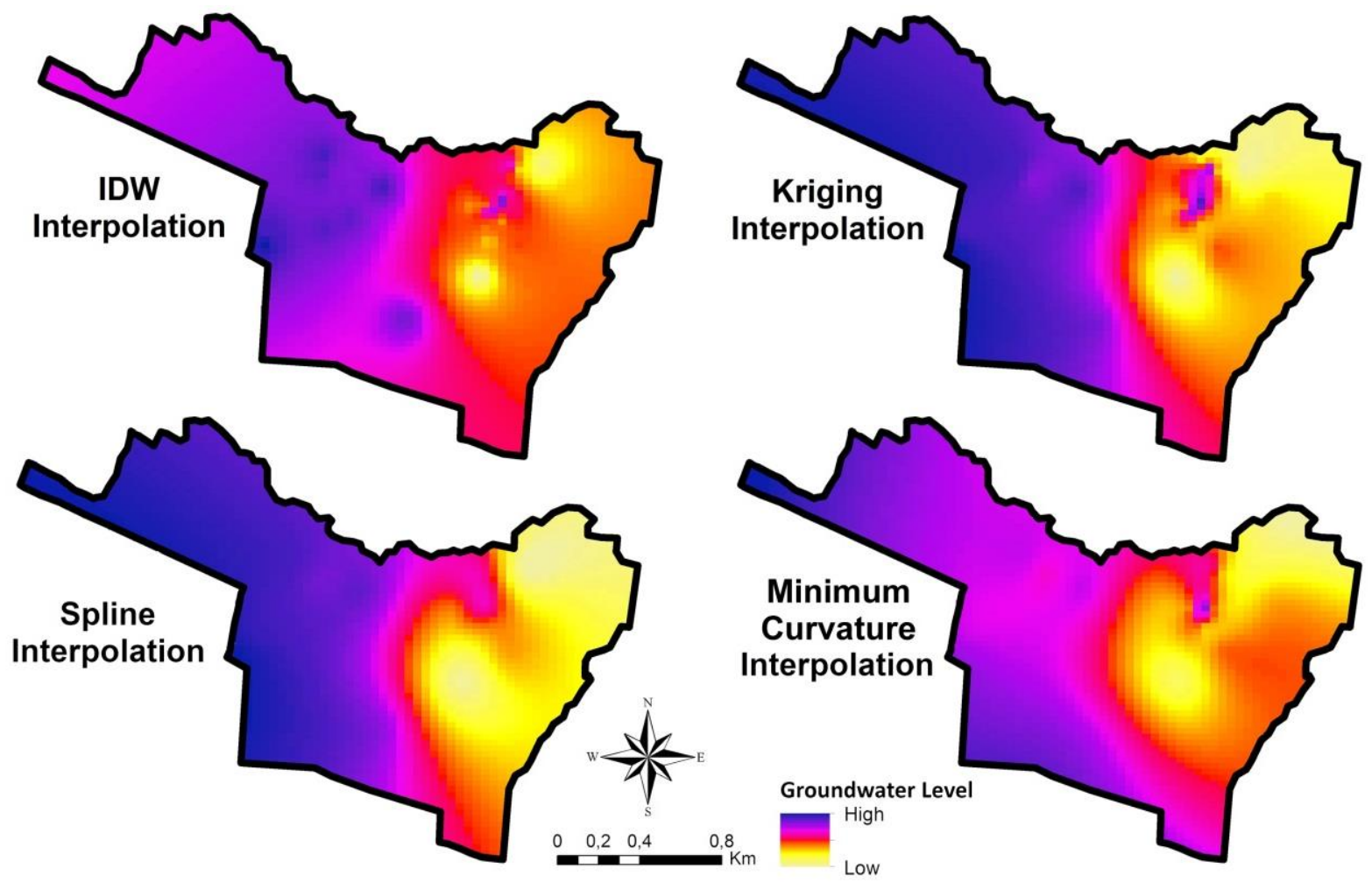

Sumber: Hasil Analisis, 2018

Gambar 3. Interpolasi Air Tanah di Desa Kayuambon
Curvature < Spline, dan koefisien determinan $\mathrm{R}^{2}$ ditunjukan bahwa nilai Kriging > IDW > Minimum Curvature > Spline. Dari ke tiga variabel ditunjukan bahwa teknik interpolasi Kriging memiliki tingkat validitas yang tinggi dibandingkan metode yang lain. Sementara itu, teknik interpolasi Spline memiliki tingkat validitas terendah.

Tinggi muka air tanah semakin turun ke arah timur, walaupun terdapat sedikit perbedaan secara minor (gambar 3). Perbedaan hasil tersebut disebabkan masing-masing teknik interpolasi memiliki cara kerja yang berbeda, baik itu secara eksak dan non-eksak (Wang dkk., 2014). Kriging, IDW, dan Spline merupakan teknik interpolasi eksak, sedangkan Minimum Curvature merupakan teknik interpolasi non-eksak. 
Tabel 1. Nilai Mean Error, RMSE and $\mathrm{R}^{2}$

\begin{tabular}{ccccc}
\hline \multirow{2}{*}{ Parameter } & \multicolumn{4}{c}{ Teknik Interpolasi } \\
\cline { 2 - 5 } & IDW & Kriging & Spline & Minimum Curvature \\
\hline ME & 0.065433 & 0.316833 & -0.3372 & $-0,19593$ \\
\hline RMSE & 11.53623 & 10.68147 & 14.57093 & 11.56109 \\
\hline $\mathrm{R}^{2}$ & 0.872433 & 0.88934 & 0.795431 & 0.868317 \\
\hline
\end{tabular}
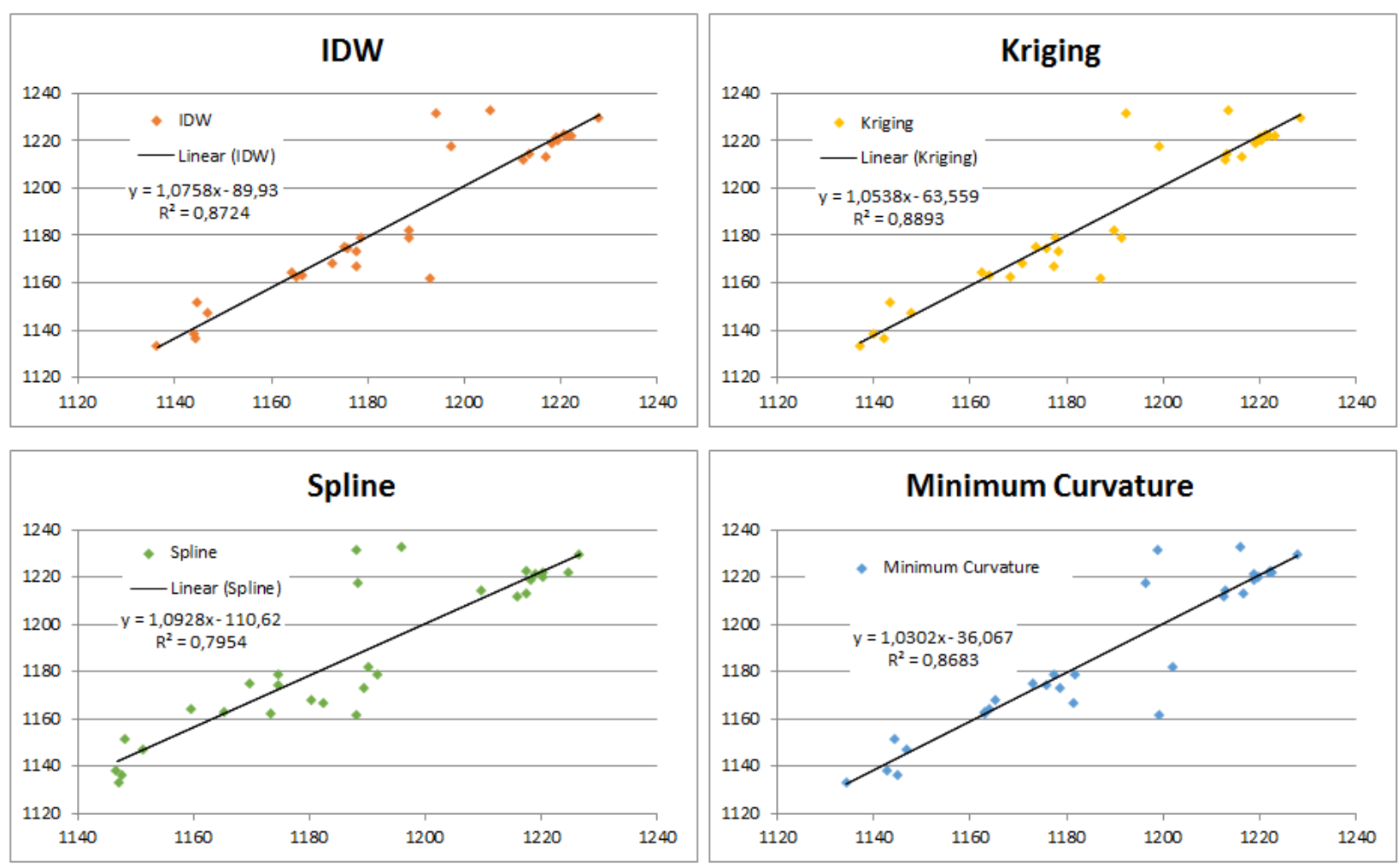

Sumber: Hasil Analisis, 2018

Gambar 4. $\mathrm{R}^{2}$ and Formula Teknik Interpolasi

Teknik interpolasi Kriging, IDW, dan Spline mampu melakukan generalisasi nilai walaupun terdapat data lokasi yang tidak diketahui nilainya. Hal ini berbeda dengan teknik interpolasi Minimum Curvature yang hanya mampu memprediksi nilai dari data lokasi yang telah diketahui nilainya (Bourgoyne dkk., 2016).

\section{Air Tanah di Desa Kayuambon}

Tinggi muka air tanah hasil pemodelan memiliki rentang nilai minimum dan maksimum yang berbeda, secara berurutan rentang nilai dari keempat teknik interpolasi yakni 1136.497 - 1228.145 mdpl (IDW), 1146.624 - 1226.73 mdpl (Kriging), 1137.202 - 1228.439 mdpl (Spline), dan 1134.3 - $1227.881 \mathrm{mdpl}$ (Minimum Curvature). Teknik interpolasi Spline dan Kriging memiliki nilai maksimum muka air tanah yang lebih tinggi. Sedangkan teknik interpolasi IDW dan Minimum Curvature memiliki nilai minimum air tanah yang lebih rendah.

Di sisi lain, nilai koefisien determinasi antar teknik interpolasi menunjukan bahwa teknik interpolasi Kriging memiliki akurasi yang paling baik seperti yang ditunjukan pada gambar 4 . Dengan demikian, teknik interpolasi kriging layak untuk memprediksi tinggi muka air tanah di Desa Kayuambon. Berdasarkan gambar 4 diketahui juga 
bahwa nilai $\mathrm{R}^{2}$ teknik interpolasi eksak tidak selalu lebih baik bila dibandingkan dengan non-eksak.

\section{Aliran Air Tanah dan Cone of Depression} Jaringan aliran air tanah (flownet) yang dibuat dengan menggunakan teknik interpolasi IDW, Kriging, Spline, dan Minimum Curvature (Gambar 5). Arah aliran tersebut dibuat secara tegak lurus dari tiap-tiap garis iso-piezometrik atau kontur air tanah hingga mencapai kontur terendah sebagai pusat akumulasi air tanah (cone of depression) dengan interval 1 meter. Pada setiap cone of depression nampak garis-garis aliran air menuju pada lokasi yang sama, hal ini menandakan bahwa air tanah dapat berkumpul di lokasi tersebut (Rhonda, 1995).

Arah aliran air tanah digambarkan dengan tanda panah berwarna merah, sedangkan cekungan air tanah (cone of depression) digambarkan dengan simbol lingkaran berwarna biru (cone of depression 1) dan ungu (cone of depression 2), serta garis iso-piezometrik digambarkan dengan warna hijau. Pada teknik interpolasi IDW, Kriging, Spline, dan Minimum Curvature pusat cekungan air tanah terdapat pada 2 (dua) lokasi. Keempat teknik interpolasi menunjukkan bahwa terdapat kesamaan lokasi cone of depression I maupun konsentrasi aliran air tanah. Namun pada cone of depression II, setiap metode menunjukkan lokasi yang berbeda-beda. Hal ini disebabkan karena perbedaan karekteristik teknik interpolasi yang digunakan (Yao dkk., 2013). Cone of depression II berada di sebelah utara desa dan berdekatan dengan aliran sungai (gambar 5 dan gambar 1). Keberadaan cone of depression menandakan tingginya tinkat pengambilan air tanah oleh masyarakat (HWE, 2009).

\section{SIMPULAN}

Hasil pemodelan ini menunjukan bahwa setiap teknik interpolasi memiliki keunggulan dan kelemahan, hal ini dapat dilihat dari nilai Mean Error (ME), Root Mean Square Error (RMSE) dan Coefisien of
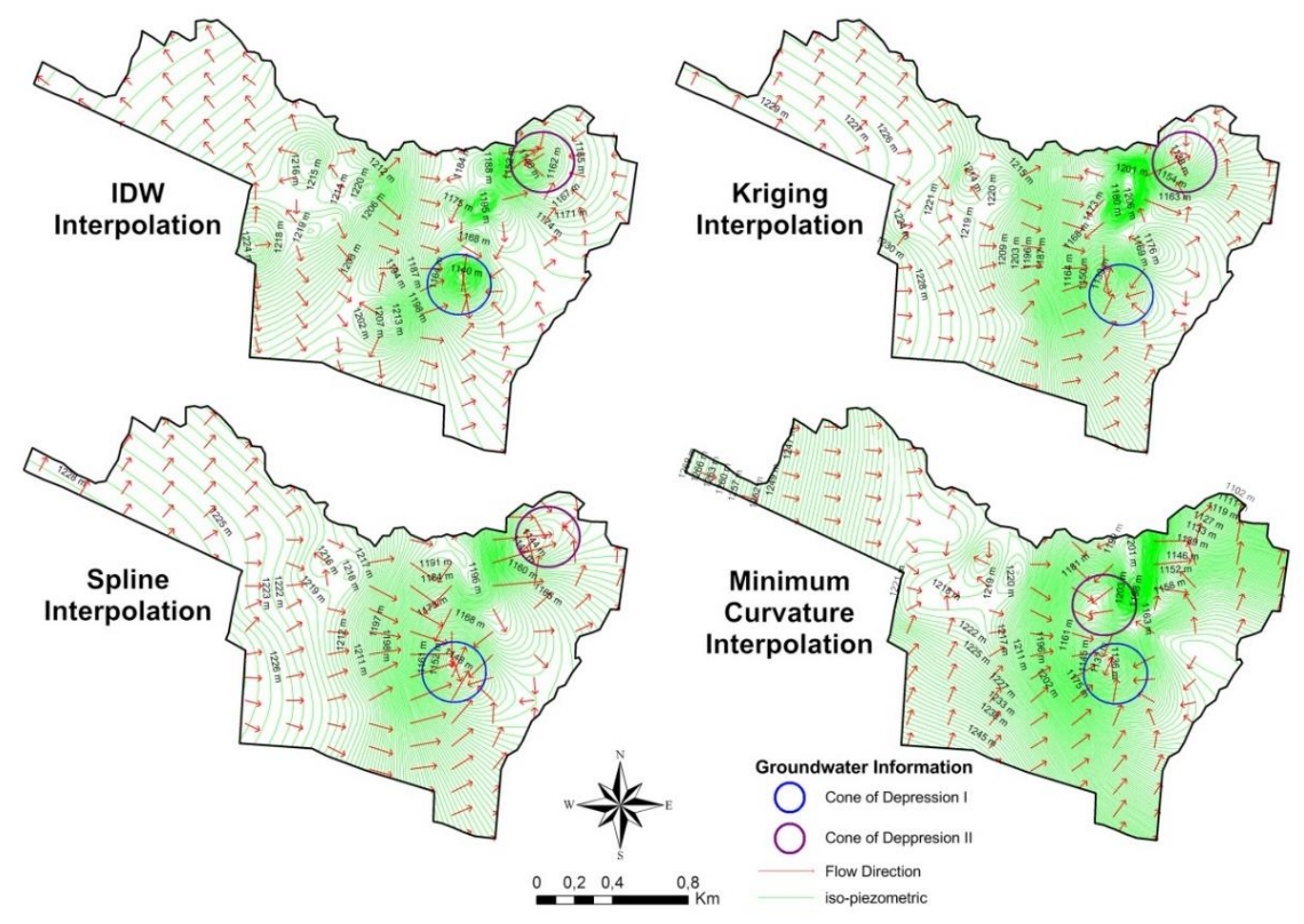

Sumber: Hasil Analisis, 2018

Gambar 5. Arah Aliran Air Tanah dan Cone of Depression di Desa Kayuambon 
Determinant $\left(\mathrm{R}^{2}\right)$. Dalam pemodelan air tanah di Desa Kayuambon, teknik interpolasi Kriging memiliki tingkat validitas tertinggi, sedangkan Spline merupakan teknik interpolasi dengan tingkat validitas terendah. Selanjutnya, arah aliran air tanah dibuat secara tegak lurus dengan iso-piezometrik (kontur) menggunakan ArcGIS, sehingga diketahui arah air tanah di Desa Kayuambon yang terakumulasi pada dua lokasi.

\section{REKOMENDASI}

Penelitian mengenai pemodelan air tanah dapat dilakukan dengan lebih baik bila pengambilan data dapat dilakukan dengan metode lain, misalnya geo-listrik. Selain itu, pemodelan air tanah yang bersifat korelatif dengan berbagai faktor lingkungan dapat dilakukan sebagai upaya dalam pengelolaan sumber daya air dan lahan, seperti perencanaan pemenuhan kebutuhan air baku, penetapan kawasan lindung, pengembangan drainase, dan mitigasi bencana hidro-meteorologis.

\section{DAFTAR PUSTAKA}

Anugrahadi, A., Purwadhi, F. S. H., dan Haryani, N. S. (2017). Terapan Penginderaan Jauh dan Sistem Informasi Geografis dalam Geologi, Geomorfologi, dan Mitigas Bencana Beraspek Hidrometeorologi. Jakarta: Universitas Trisakti Jakarta.

Baalousha, H. (2008). "Fundamentals of Groundwater Modelling". on Konig, L. W. \& Weiss, J. L. (eds.). Groundwater: Modelling, Management and Contamination. New York: Nova Science Publishers, Inc.

BPS Kab. Bandung Barat. (2016). Bandung Barat Regency in Figures. Bandung: BPS Kab. Bandung Barat.
Bourgoyne, A.T., dkk. (2016). Applied Drilling Engineering. Texas: Society of Petroleum Engineers, Inc.

Charoenpong, S ., Suwanprasit, D. dan Thongchumnum, P. (2012). "Impacts of Interpolation Techniques on Groundwater Potential Modelling using GIS in Phuket Province, Thailand". Proceeding the $33^{\text {rd }}$ Asian Conference of Remote Sensing, November $26^{\text {th }}-30^{\text {th }}, 2013$ at Pataya, Thailand, pp. $1-7$.

Dressler, M. (2009). Art of Surface Interpolation. Kunštát: Technical University of Liberec.

Hadi, B. S. (2013). “Metode Interpolasi Spasial Dalam Studi Geografi (Ulasan Singkat dan Contoh Aplikasinya)". Geomedia, 11 (2): 235 252.

HWE. (2009). Groundwater Engineering. Ramallah: Birzeit University \& House and Water Environment Publication.

Keckler, D. (1994). Surfer for Windows: User Guide. Colorado: Golden Software, Inc.

Kresic, N. (2007). Hydrogeology and Groundwater Modelling. New York: CRC Press.

Kumar, C. P. (2015). "Modelling of Groundwater Flow and Data Requirements". International Journal of Modern Sciences and Engineering Technology, 2 (2): 18 - 27.

Pasaribu, J. M. dan Haryani, N. S. (2012). "Perbandingan Teknik Interpolasi DEM SRTM dengan Metode Inverse Distance Weight (IDW), Natural Neighbor dan Spline". Pusat 
Pemanfaatan Penginderaan Jauh, Lapan, 9 (2): 126 - 139.

Pramono, G. H. (2008). “Akurasi Metode IDW dan Kriging untuk Interpolasi Sebaran Sedimen Tersuspensi". Forum Geografi, 22 (1): 97 - 110.

Qiu, S., dkk. (2015). “Numerical Simulation of Groundwater Flow in a River Valley Basin in Jilin Urban Area, China". Journal of Water, 7 (10): 5768 - 5787.

Rhonda, G. M. (1995). Groundwater Modelling Calculation for the Cone of Depression. Retrieved at http://math.clemson.edu/ warner Lground.pdf. Accessed on Feb 17th, 2018.

Saldanela, S., Sutikno, S., dan Hendri, A. (2015). "Pemetaan Pola Aliran Air Tanah Berabasis Sistem Informasi Geografis (SIG) di Kawasan Kecamatan Tampan Kota Pekanbaru". Jurnal Jom FTEKNIK, 2 (1): 1 - 8 .

Sarangi, A., Cox, A., dan Madramootoo, C. A. (2005). "Geostatistical Methods for Prediction of Spatial Variability of Rainfall in a Mountainous Region". Journal American Society of Agricultural Engineers, 48 (3): 943 954.

Silitonga, P. H. (1973). Geologic Map of the Bandung Quadrangle. Bandung: Geological Survey of Indonesia.

Sun, Y., dkk. (2009). "Comparison of Interpolation Methods for Depth to Groundwater and its Temporal and Spatial Variations in the Minqin Oasis of Northwest China". Journal of
Environmental Modelling E Software, 24 (10): 1163 - 1170.

Tonkin, M. J. dan Larson, S. P. (2001). "Kriging Water Levels with a Regional-Linear and PointLogarithmic Drift". Journal of Groundwater, 4 (2): 185 - 193.

UNESCO. (2005). Groundwater Resource Issues, Problems, and Recommendations. Tersedia di https://srbc.net/programs/docs/G WMngtPlanJune2005/2.0\%20\%20Gr oundwater \%20Resource \%20Issues, \%20Proble ms, \%20and \%20Recommendations.p df. Diakses pada 17 Februari 2018.

Wang, S., dkk. (2014). “Comparison of Interpolation Methods for Estimating Spatial Distribution of Precipitation in Ontario, Canada". International Journal of Meteorology, 34: 3745 - 3751.

Winter, T. C., dkk. (1998). Ground Water and Surface Water: a Single Resource. Denver: U.S. Government Printing Office.

Xiao, Y., dkk. (2016). "Geostatistical Interpolation Model Selection Based on ArcGIS and Spatio-Temporal Variability Analysis of Groundwater Level in Piedmont Plains, Northwest China". Journal SpringerPlus, 5 (425): 2 - 15.

Yao, X., dkk. (2013). “Comparison of Four Spatial Interpolation Methods for Estimating Soil Moisture in a Complex Terrain Catchment". Journal PLoS ONE, 8 (1): 1 - 13. 